\title{
The Influence of Principal Leadership and Principal Work Discipline on Teacher Performance in SD Negeri Sungai Menang District
}

\author{
Muhadi $^{1 *}$, Bukman Lian², Mulyadi ${ }^{2}$ \\ ${ }^{1}$ SD Negeri 3 Pratama Mandira \\ ${ }^{2}$ Universitas PGRI Palembang \\ "Corresponding Author. Email: adimuhadi683@gmail.com
}

\begin{abstract}
This research is a study to answer assumptions about the influence of principal leadership and principal work discipline on teacher performance. Therefore, the description of the research carried out refers to the quantitative descriptive research method. Through data obtained from questionnaires, documentation and observation then analyzed by parametric statistics. The results of the analysis conducted state that the principal's leadership has a positive and significant effect on teacher performance; Likewise with partial testing for other variables that the principal's work discipline is able to have a positive and significant effect on teacher performance; Simultaneously, the leadership of the principal and the discipline of the work of the principal were able to have a positive and significant effect on teacher performance in SD Negeri in Sungai Menang District.
\end{abstract}

Keywords: principal leadership, work discipline, teacher performance.

\section{INTRODUCTION}

Various technologies are present in human life today, as a result of thinking that is assumed to be quality educational output. Because until now, proper education is a necessity for everyone. This is due to the public awareness of the importance of education as a provision for competing in the global era. Each stakeholder should understand their respective roles as an effort to optimize learning and the quality of education as a whole. At the level of the most operational educational institution, namely the school, a leader known as the principal must be sensitive to the current conditions that are happening around him. A good leader, then not only leads administratively but also shows his leadership side in managing every aspect that is his responsibility.

Principal leadership is needed to optimize learning and the quality of education in schools. Because the principal has the authority to regulate and manage all the resources available in his school. As stated that leadership is the art of persuading subordinates to be willing to do tasks with confidence and enthusiasm. So, with the right leadership it will produce quality education through quality learning [1].

The leadership of a school principal will determine the quality of the education held at the school. Authority regarding the budget, which includes the fulfillment of school supplies, is also led directly by the principal. With this authority, it is very possible for a principal to have innovative breakthroughs in order to provide quality education.

According to Kristiawan, that a school principal has a duty to provide a positive influence, encouragement to be better, provide guidance in carrying out tasks, provide direction, and become a driving force for teachers, education personnel, students, parents and parties with an interest in working and playing a role. in order to achieve the goals set [2]. To achieve this, a school principal must have qualified competencies, so that the responsibilities that are mandatory for him can be properly resolved.

Optimization of teacher work in carrying out their duties can be carried out by the principal, so that 
effective learning can be achieved. Because teachers as professionals who work in a school unit will be responsible to the school principal. The principal as the highest leader who is very influential and determines the progress of the school must have administrative skills, have high commitment, and be flexible in carrying out his duties. Good principal leadership must be able to strive to increase teacher competence through educational staff capacity building programs. Therefore, the principal must have the personality or traits and abilities and skills to lead an educational institution. In his role as a leader, the principal must be able to pay attention to the needs and feelings of the people who work so that teacher competence is always maintained.

If this can be implemented properly by the principal, then it will clearly have a positive impact on the educational institutions he leads. It is understood that all these activities will lead to the implementation of quality learning. The quality of learning in the classroom will largely depend on how the teacher works in implementing learning. A teacher who is directly responsible to the school will get a moral burden if he does not do his job well, if the principal has shown a good leadership attitude and is able to be disciplined in all activities.

Teachers who have a position as professional staff have responsibilities that have been regulated in Law Number 14 of 2005 concerning Teachers and Lecturers, article 1 paragraph (1) states that teachers are professional educators with the main task of educating, teaching, guiding, directing, training, assessing, and evaluating students in early childhood education through formal education, basic education, and secondary education [3]. There is also an affirmation regarding the duties of teachers in the Regulation of the Minister of Education and Culture Number 23 of 2017 article 1 paragraph (3) that teachers are professional educators with the main task of educating, teaching, guiding, directing, training, assessing, and evaluating students in the education of children aged early pathways of formal education, basic education, and secondary education [4].

Therefore, it is hoped that the implementation of learning in the classroom can be carried out properly by the teacher as part of their performance. Teacher performance is one measure of the professionalism of teachers in carrying out the mandate given to them. Through the Regulation of the Minister of National Education Number 41 of 2007, states that teacher performance as teaching achievement resulting from activities carried out by teachers in their main tasks and functions in a concrete realization is a logical consequence of being a professional in education [5].

When referring to the description above, it is clear that good principal leadership by also showing a form of discipline in carrying out its duties, is believed to be able to have an impact on teacher performance in implementing learning in the classroom. In order for this research to run properly, the researchers conducted a preliminary study on the object of research. Information or findings from studies conducted that the perception of the principal only running the administrator aspect and not displaying the leadership aspect optimally is the perception of the teachers. This is also based on the not yet good work discipline of a school principal, because the principal's attendance is not optimal. Because of this, researchers also found a phenomenon that indicates that teacher performance has not been optimal, this is obtained through incomplete learning administration.

\section{METHOD}

Researchers used several locations in the implementation of this research. It is clearer that this research was conducted at public elementary schools in Sungai Menang District. The research time was started from July to October 2020. This research used a quantitative descriptive method, as it is known that this research will test the hypothesis. [6] that the descriptive method is a method of examining the status of a group of people, an object, a set of conditions, a system of thought, or a class of events at present. Descriptive type research is carried out with the aim of describing facts about related information population systematically, and accurately. When using a descriptive research approach, the facts obtained from the research results will be presented as they should or as they are.

[7] Descriptive research is a form of research conducted with the aim of finding out the existence of independent variables, either in one particular variable or even more than one variable, without making a comparison or linking it with other variables.

[7] emphasized that quantitative research is a study that obtains numerical data or it can be extrapolated qualitative data. A quantitative approach is used to measure the variables in this study, namely the variables $\mathrm{X} 1, \mathrm{X} 2$ and $\mathrm{Y}$ and then look for the relationship between these variables.

The sample of this study amounted to 78 from a population of 243 . The sample was taken using purposive sampling technique. Data obtained through questionnaires, documentation and observation.

\section{RESULTS AND DISCUSSION}

This study has tested the data obtained beforehand, so that it is known that the data is normally distributed and there are no symptoms of heteroscedasticity.

The first hypothesis testing states that the tcount for the principal's leadership variable is $10.554>\mathrm{t}$ table, which is 1.992, which means that the alternative hypothesis (Ha) for testing hypothesis 1 is accepted. Therefore, it is stated that the leadership of the principal 
has a positive and significant effect on the performance of teachers in SD Negeri in Sungai Menang District, Ogan Komering Ilir Regency.

The correlation coefficient or the magnitude of the relationship between principal leadership and teacher performance is $77.1 \%$, and is included in the strong relationship category. The determinant coefficient or the magnitude of the influence of the principal's leadership variable on teacher performance is $59.4 \%$, which means it has a high enough influence.

The second hypothesis testing obtained the value of $t>t$ table; 10,026>1,992. Based on this, it is concluded that the alternative hypothesis is accepted, which means that the principal's work discipline has a positive and significant effect on the performance of teachers in SD Negeri in Sungai Menang District, Ogan Komering Ilir Regency.

The correlation coefficient or the magnitude of the relationship between the principal's work discipline and teacher performance is $75.5 \%$. The magnitude of the relationship, belongs to the close category. The determinant coefficient or the magnitude of the influence of the principal's work discipline variable on the performance of teachers in SD Negeri in Sungai Menang District, Ogan Komering Ilir Regency is $56.9 \%$ and is included in the category of high enough influence.

Testing the third hypothesis, obtaining the results of the Fcount value of 77.384> FTabel of 3.119 which means that there is a positive and significant influence on the leadership of the principal and the work discipline of the principal on the performance of teachers in SD Negeri in Sungai Menang District, Ogan Komering Ilir Regency.

As much as $82.1 \%$ jointly, the leadership of the principal and the discipline of the principal's work influenced the performance of teachers in SD Negeri in Sungai Menang District, Ogan Komering Ilir Regency, thus included in the category of close or high relationships. The leadership of the principal and the work discipline of the principal together have an effect on the performance of teachers in SD Negeri in Sungai Menang District, Ogan Komering Ilir Regency by $67.4 \%$ and it is included in the category of quite high influence.

\subsection{The influence of principal leadership on teacher performance}

The results achieved in this study certainly provide confirmation to previous research, as has been done by [8] that principal leadership is able to have a positive and significant impact on the performance of vocational teachers. Thus, the results of this study provide approval for the results achieved by Purwoko. Another research that is also supported by these results is research [9], which states that the leadership of the principal has a positive impact on the performance of MTs N Batudaa teachers in Gorontalo District.

The same thing also happened to research conducted by [10], [2], [11] which overall stated firmly that the principal's leadership was able to optimize teacher performance in carrying out their duties. Therefore, it is clear the consistency of this variable in influencing teacher performance at every level of education.

Likewise, with research conducted by [12]; [13]; [14]; [22] that principal leadership can not only have a positive impact on teacher performance but also on the effectiveness of learning. When viewed from the results of research [15] [16] [17] that it is true that the leadership of the principal is able to have a positive and significant impact on the achievement of better teacher performance.

Not so different from the results achieved through research [18] [19] that teacher performance and the quality of education can be positively influenced by good principal leadership. Therefore, it is fitting that the principal be a role model for every member of the school community.

\subsection{The influence of the principal's work discipline} on teacher performance

This study also supports the research conducted by [8], that work discipline can have a positive and significant effect on the performance of vocational teachers. Likewise, with research conducted by Ngiode (2016), as well as [20], which states that work discipline has a positive influence on the performance of teachers of SMP Negeri Kotabumi District, North Lampung Regency. These results become more emphatic with the existence of this research, because through this research the researchers agree and agree with the results that have been achieved by previous studies.

3.3. The influence of principal leadership and principal work discipline on teacher performance

The results of this study also support the research conducted by [8], [20], which states that principal leadership and work discipline are able to have a positive and significant influence on the performance of teachers of SMP Negeri Kotabumi District, North Lampung Regency. For this reason, this study has confirmed previous research and the consistency of these independent variables is simultaneously proven through the results obtained [22]; [23].

\section{CONCLUSION}

Based on the results of data analysis and processing as well as discussion of the findings of this study, it is stated that: 1) the leadership of the principal has a positive and significant effect on the performance of teachers in SD Negeri in Sungai Menang District, Ogan Komering Ilir Regency; 2) The principal's work 
discipline has a positive and significant effect on the performance of teachers in SD Negeri in Sungai Menang District, Ogan Komering Ilir Regency. 3) the leadership of the principal and the work discipline of the principal together have a positive and significant effect on the performance of teachers in SD Negeri in Sungai Menang District, Ogan Komering Ilir Regency. The magnitude of the effect simultaneously is sixtyseven point four percent and is included in the fairly high influence category.

\section{REFERENCES}

[1] Mulyasa. (2013). Menjadi kepala sekolah profesional. Bandung: Remaja Rosdakarya.

[2] Setiyati, S. (2014). Pengaruh kepemimpinan kepala sekolah, motivasi kerja dan budaya sekolah terhadap kinerja guru. Jurnal Pendidikan Teknologi dan Kejuruan, Volume 22 Nomor 2, 200-207.

[3] Pemerintah Republik Indonesia. (2005). UndangUndang Nomor 14 Tahun 2005 tentang Guru dan Dosen. Jakarta: Pemerintah Republik Indonesia

[4] Kementerian Pendidikan dan Kebudayaan. (2017). Peraturan Menteri Pendidikan dan Kebudayaan Nomor 23 Tahun 2017 tentang Hari Sekolah. Jakarta: Kementerian Pendidikan dan Kebudayaan.

[5] Kementerian Pendidikan Nasional. (2007). Peraturan Menteri Pendidikan Nasional Nomor 41 Tahun 2007 tentang standar proses untuk satuan pendidikan dasar dan menengah. Jakarta: Kementerian Pendidikan Nasional.

[6] I. Fathurrochman, S. Danim, S. A. Ab, and N. Kurniah, "The School Principals' Role in Education Management at the Regional Level : An Analysis of Educational Policy in the Industrial Revolution 4 . 0," no. 532, pp. 237-242, 2021.

[7] Nazir, M. (2011). Metode penelitian. Jakarta: Ghalia Indonesia.

[8] Sugiyono. (2017). Metode Penelitian Kualitatif, Kuantitatif dan R\&D. Bandung: Alfabeta

[9] Purwoko, S. (2018). Pengaruh kepemimpinan kepala sekolah, komitmen guru, disiplin kerja dan budaya sekolah terhadap kinerja guru SMK. Jurnal Akuntabilitas Manajemen Pendidikan, Volume 6 Nomor 2, 149-162.

[10] Ngiode, S. (2016). Pengaruh kepemimpinan kepala sekolah, motivasi kerja dan disiplin kerja terhadap kinerja guru MTs N Batudaa Kabupaten Gorontalo. TADBIR: Jurnal Manajemen Pendidikan Islam, Volume 4 Nomor 2, 127-137.

[11] Imam Tobroni, S. R., Pelana, R., Sianipar, G., Guefara, R. L., \& Fathurrochman, I. (2020). Covid 19: Political Cooperation and Ritual Modification of Religious Worship Through Large-Scale Social Restrictions. Systematic Reviews in Pharmacy, 11(12), 644-648.
[12] Pegita, T. (2015). Pengaruh kepemimpinan kepala sekolah dan disiplin kerja guru terhadap kinerja guru. Yogyakarta: Universitas Sanatha Dharma.

[13] Imansyah, M., Arafat, Y., \& Wardiah, D. (2020). Pengaruh kepemimpinan kepala sekolah dan partisipasi komite sekolah terhadap kinerja guru. Jurnal Manajemen, Kepemimpinan dan Supervisi Pendidikan, 135-143

[14] Achmad, A. (2015). Pengaruh Kepemimpinan Kepala Sekolah dan Kinerja Guru terhadap Efektivitas Pembelajaran Agama Islam. Bandung: UIN Sunan Gunung Djati.

[15] Baihaqi, M. I. (2015). Pengaruh gaya kepemimpinan kepala sekolah dan motivasi kerja terhadap kinerja guru di MA Ma'arif Selorejo Blitar. KONSTRUKTIVISME, Volume 7 Nomor 2, 97-106.

[16] Banani, M. T. (2017). Pengaruh Kepemimpinan Kepala Sekolah terhadap Kompetensi Guru dalam Mewujudkan Efektivitas Pembelajaran. Jurnal Pendidikan UNIGA, Volume 11 Nomor 1.

[17] Gumilar, G. G., \& Munzir, T. (2018). Pengaruh gaya kepemimpinan kepala sekolah terhadap kinerja guru SMA Global Indo-Asia Batam. Jurnal Dimensi, Volume 7 Nomor 2, 255-266.

[18] Mutmainah. (2016). Pengaruh kepemimpinan kepala sekolah dan profesionalitas guru terhadap kinerja guru SMK Negeri 1 Tepus. Yogyakarta: Universitas Negeri Yogyakarta.

[19] Rukmana, A. (2018). Pengaruh gaya kepemimpinan kepala sekolah dan motivasi kerja guru terhadap kinerja guru. Coopetition, Volumen 9 Nomor 1, 77-93.

[20] Priyono, \& Rahayu, A. (2016). Pengaruh gaya kepemimpinan kepala sekolah, motivasi kerja, dan kedisiplinan terhadap pengembangan karier guru SMK di Kabupaten Boyolali. QUALITY, Volume 4 Nomor 1, 25-44.

[21] Ningsih, K. D., Harapan, E., \& Destiniar. (2021). Pengaruh komite sekolah dan kepemimpinan kepala sekolah terhadap peningkatan mutu pendidikan. Jurnal Manajemen, Kepemimpinan dan Supervisi Pendidikan, Volume 6 Nomor 1, 1-14.

[22] Ismarini, E., Djasmi, S., \& Suntoro, I. (2017). Pengaruh kepemimpinan kepala sekolah, disiplin kerja dan iklim kerja sekolah terhadap kinerja guru SMP Negeri Kecamatan Kotabumi Kota Kabupaten Lampung Utara. Jurnal Manajemen Mutu Pendidikan.

[23] Murfi, A., Fathurrochman, I., Atika, A., \& Jannana, N. S. (2020). Kepemimpinan Sekolah dalam Situasi Krisis Covid-19 di Indonesia. MANAGERIA: Jurnal Manajemen Pendidikan Islam, 5(1), 119136. 